\title{
O bacharelismo interventor no pensamento político brasileiro: uma abordagem comparativa entre Rui Barbosa e Rodrigo Janot \\ Rodrigo Perez Oliveira
}

\section{Rodrigo Perez Oliveira}

Doutor em História Social. Professor Adjunto de Teoria da História e Historiografia Brasileira da Universidade Federal da Bahia.

Email: rodrigoperez@ufba.br

ORCID: https://orcid.org/0000-0002-9584-944X

\begin{abstract}
Resumo
O objetivo deste artigo é examinar a atuação de Rui Barbosa e Rodrigo Janot em seus respectivos cenários de crise. Rui Barbosa agiu na a crise da Monarquia, que resultou na República. Janot agiu na crise da IV República, que ainda não sabemos em que resultará. Parto da premissa de que a atuação desses dois personagens foi prefigurada por um mesmo pensamento político, que conceituo com o termo "bacharelismo interventor". Em momentos em que as instituições estabelecidas estavam desmoronando, Rui Barbosa e Rodrigo Janot defenderam a importação de leis pertencentes ao direito dos EUA para organizar um novo contrato social e sanear costumes políticos corrompidos. Essa importação, contudo, não seria feita pelo simples transplante institucional, mas sim através de um esforço de adaptação coordenado pelo bacharel interventor, tratado por pelos dois personagens como um tipo de herói cívico capaz de viabilizar a realização de uma utopia política. Para Rui Barbosa, a utopia era a democracia liberal. Para Janot, a utopia era a plena representação política. No texto, meu esforço é dar contornos mais precisos ao que a bibliografia especializada costuma chamar de "ativismo político do judiciário".
\end{abstract}

\section{Palavras Chave}

Rui Barbosa, Rodrigo Janot, Crise Institucional, Bacharelismo Interventor 
Rodrigo Perez Oliveira

\title{
Introdução
}

\begin{abstract}
E, ao passo que os mais altos espíritos veem na educação legalista, no entranhado constitucionalismo dos americanos, o princípio da virilidade incomparável daquele povo, nós, que fomos buscar no seu exemplo a forma da nossa reconstituição liberal, iniciamos o novo regime com um eclipse total da consciência jurídica, de que não nos salvaremos, se a justiça da República não nos oferecer, na organização e no papel deste tribunal, o órgão de reparação que sob a Monarquia nos faltava. (BARBOSA, 1892: 06)

Desde a década de 1990, existe o interesse do Ministério Público brasileiro na importação do instituto do acordo penal, tal como se apresenta na jurisdição dos EUA, que pertence a outra família da tradição jurídica, que não aquela continental, à qual pertence a cultura jurídica brasileira. $O$ instituto do acordo penal é um requisito fundamental para a regeneração dos costumes políticos brasileiros (BARROS, julho de 2017).
\end{abstract}

Mais de 120 anos separam as duas citações. Na primeira, Rui Barbosa (1849-1923) apela ao Supremo Tribunal Federal em defesa dos presos políticos da ditadura florianista (1891-1894), apontando a incompatibilidade entre a tirania militar e o liberalismo republicano de matriz anglo-saxã instituído no Brasil pela Constituição de 1891. Na segunda citação, Rodrigo Janot Monteiro de Barros, Procurador Geral da República entre 2013 e 2017, apresenta, em conferência pronunciada nos EUA, os resultados da incorporação do "instituto do acordo penal" ao direito brasileiro. Cada qual no seu tempo, tanto Rui Barbosa como Rodrigo Janot atuaram em experiencias de intensa crise política e institucional. Rui Barbosa viveu a transição da Monarquia para a República. Rodrigo Janot viveu o colapso da IV República. Meu objetivo neste artigo é examinar o pensamento político que prefigurou a atuação desses dois personagens.

Ainda que as experiências da crise da Monarquia e da crise da IV República sejam bastante diferentes, a análise das atuações de Rui Barbosa e Rodrigo Janot nos permite falar na sobrevivência de uma determinada "forma de pensar a política", para utilizar os termos de Gildo Marçal Brandão (BRANDÃO, 2005). Chamo de "bacharelismo interventor" essa forma de pensamento. Minha hipótese neste artigo, portanto, é de que o bacharelismo interventor pode ser identificado nas atuações de Rui Barbosa e Rodrigo Janot em seus respectivos cenários de crise. O bacharelismo interventor se caracteriza por uma percepção messiânica da lei, segundo a qual o direito positivo, e o legislador, têm capacidade de sanear costumes degenerados. Este argumento está presente tanto no texto de Rui Barbosa como no pronunciamento de Rodrigo Janot. Os dois personagens afirmam que os costumes brasileiros estavam corrompidos, o que exigia, na avaliação de ambos, a importação de instrumentos jurídicos virtuosos originários do liberalismo anglo-saxão, especialmente dos EUA.

O texto está dividido em três partes: primeiro, examino a atuação de Rui Barbosa na crise da Monarquia e nos primeiros anos da República. Depois, trato da atuação de Rodrigo Janot na crise da IV República. Por último, comparo os dois, tomando como objeto de análise seus textos e pronunciamentos.

\subsection{Rui Barbosa e a instituição da República}

A corrente se avoluma, e dia a dia redobra de força: ontem pobre vertente, depois regato: hoje rio majestoso, amanhã será oceano [...] como dizem todos que verdadeiramente se interessam pela sorte da 
Rodrigo Perez Oliveira

nação: reformai sem demora, reformai radicalmente este sistema corrompido; aliás, quando procurardes pelas instituições, elas se terão afundado no abismo com o sistema que a elas se agarrando, como nociva parasita, as desconjuntam, e abalam em seus fundamentos. (BARBOSA, 1873: 12)

A vida pública de Rui Barbosa começou no final da década de 1860, quando ele concluiu o curso na Faculdade de Direito de São Paulo. Na citação, Rui nos apresenta um valioso testemunho daquela que a bibliografia especializada considera ter sido a primeira grande crise da Monarquia brasileirai. Quando o Imperador D. Pedro II interferiu no jogo político para derrubar o gabinete ministerial chefiado pelo liberal Zacarias de Gois e Vasconcelos (1815-1877), alguns políticos liberais se sentiram traídos e cada vez mais passaram a marchar juntos, no sentido da adesão ao republicanismo, que passou a ter representação partidária em 1870, quando foi fundado o Partido Republicano. Foi nessa conjuntura que Rui Barbosa discursou, em 1873, no Teatro São José, em Salvador, onde se apresentou como um "reformista". Poucos dias depois, a conferência foi publicada no jornal "Diário da Bahia", com o título "Eleição direta". Sem defender a derrubada da Monarquia, o jovem bacharel afirmou a necessidade de uma "reforma ampla" no regime político que ele considerava corrompido em seus fundamentosii. Mas o que significava "reforma" no vocabulário político de Rui Barbosa?

Aqueles eram tempos de acalorado debate público e de profundo questionamento às instituições. Os liberais alijados do governo pela canetada do Imperador lançaram a máxima "reforma para conjurar a revolução", como dizia o manifesto do Centro Liberal, publicado em 1869. No momento em que Rui Barbosa estreava na cena política, a "reforma" era apresentada como uma medida profilática para evitar a revolução. A reforma visava a transformação das instituições políticas para que a revolução não alterasse as estruturas sociais. O reformismo liberal do qual Rui Barbosa se tornou a principal voz partia da premissa de que os problemas da sociedade poderiam ser resolvidos por mudanças nas instituições.

Quando após o atrevido golpe de Estado deixou caracterizado na história deste país o estigma de estelionato político, o Partido Liberal, no programa de 1869 , com aquele brado solene de reformas, assinalou a revolução como consequência da negação das reformas [...]. Pois bem, no breve termo de só quatro anos que vem de 69 para cá, o círculo providencial dos acontecimentos se tem apertado com tanta força que a sessão de 3 do corrente, na Câmara vitalícia, acabou de assentar os termos da grande contenda do país contra 0 poder pessoal. [...] A não ser assim, acrescentou o nobre senador [Saraiva] profeticamente "dentro em dez anos as instituições atuais estarão demolidas". [...] O discurso do Conselheiro Saraiva é o complemento, a garantia, a justificação do programa de 1869: A Reforma ou a Revolução dentro de Dez Anos. [...] O Sr. Presidente do Conselho [visconde do Rio Branco] pôs, portanto, ao país o seguinte dilema: ou a eleição direta ou a monarquia! Santa sabedoria conservadora! (BARBOSA, 1873: 17-20).

Rui Barbosa está definindo como "golpe de Estado" a demissão do gabinete chefiado por Zacarias Vasconcelos. A intervenção de D. Pedro II era amparada pela constituição vigente à época e Rui Barbosa sabia muito bem disso. Ainda assim, ele insistiu em chamar de "golpe" aquilo que era o exercício de um preceito constitucional. É que a crítica de Rui Barbosa não se dirigia apenas ao comportamento político de Pedro II. O alvo da crítica eram as instituições da Monarquia, era a própria constituição. O ato do Imperador era considerado 
Rodrigo Perez Oliveira

ilegítimo, pois não tinha respaldo nos "parâmetros universais que distinguem a civilização da barbárie, a ordem da anarquia, a liberdade da tirania" (IDEM). Não era o imperador o autor do golpe, mas sim a constituição que lhe permitia agir assim. As instituições, portanto, deveriam ser reformadas, o poder do Imperador diminuído e eleições diretas adotadas. A terapia para os problemas da nação começava pela reforma das instituições, uma reforma que não deveria ser feita no escuro, que deveria ser pautada nos "exemplos exitosos já conhecidos" iii. Por "exemplos exitosos" leia-se Inglaterra. Desde a juventude que Rui Barbosa admirava as instituições anglo-saxãs. Se quando reformista da Monarquia, ele evocou o exemplo das instituições britânicas, quando legislador da República, as instituições norte-americanas passaram a ser seu modelo de inspiração.

Seria equivocado, contudo, acreditar que o reformismo barbosiano se resumia à simples imitação institucional, conforme afirmaram seus detratores. A recepção da obra de Rui Barbosa foi marcada pela chave de leitura forjada por escritores conservadores e antiliberais. Já nos primeiros meses da República, Eduardo Prado (1860-1901), intelectual paulista que se lançou na jornada da restauração monárquica, atribuiu a Rui Barbosa a pecha de "bacharel formalista", concepção que por muito tempo definiu o lugar do político e intelectual baiano na história do pensamento social brasileiro. Nas palavras de Prado:

Para ele, [Rui Barbosa], tudo parece simples, tudo imagina possível. $O$ direito de fazer leis é considerado pelo ilustre Ministro como uma espécie de solução milagrosa para todos os problemas sociais e políticos. O Dr Rui Barbosa já é considerado na Europa um estadista da estirpe hispânica: pouco prudente e exagerado nas suas ambições salvadoras. (PRADO, 2003: 09).

Para Prado, Rui Barbosa, então Ministro da Fazendo do governo provisório de Deodoro da Fonseca (1827-1892), se autodenominava como o pai das instituições republicanas, mas não passava de um reles imitador das instituições dos EUA: "as instituições republicanas não foram criadas e sim imitadas. (...) Rui Barbosa não é o pai da República; é imitador dos EUA" (IDEM, p. 11). A interpretação que pintou a imagem de Barbosa como imitador e importador de instituições teve vida longa e foi alimentada por outros autores de matriz conservadora, como Oliveira Viana (1883-1951), Alberto Torres (1865-1917) e Azevedo Amaral (1881-1942). Mais recentemente, a obra de Rui Barbosa vem sendo relida e essa imagem questionada. Bolívar Lamounier, por exemplo, afirma que:

Mesmo admirando às instituições anglo-saxãs, Rui Barbosa jamais considerou a possibilidade de que o simples transplante institucional seria o suficiente para resolver os dilemas brasileiros. Por isso, desde a década de 1870 , Rui militou em defesa de uma ampla reforma educacional no Brasil como meio para preparar os costumes nacionais à recepção das instituições consideradas superiores. (LAMOUNIER, 1999: 73)

Feita a ressalva, é ponto pacífico na bibliografia especializada a importância que Rui Barbosa atribuiu às instituições. Para ele, as instituições eram as responsáveis por distanciar a humanidade da barbárie, conduzindo-a à civilização, entendida como o reino das liberdades individuais. Esse apelo à institucionalidade foi o fio condutor da atuação política de Rui Barbosa nas décadas de 1870 e 1880, quando exercendo mandato de Deputado na Assembleia da Corte, ele participou ativamente de todas reformas institucionais que foram discutidas naquela casa: reforma eleitoral, reforma no sistema de ensino e reforma abolicionista (ALBUQUERQUE, 2011). 
Rodrigo Perez Oliveira

Rui Barbosa foi reformista até às vésperas da proclamação da República. Até o último momento, ele acreditou na capacidade da Monarquia em mudar sua "alma institucional", afastando-se da herança ibérica e adotando a influência inglesa, tornando-se uma "democracia federativa coroada". Apenas em junho de 1889, Rui Barbosa aderiu publicamente à causa republicana, ao recusar o convite de Afonso Celso de Assis Figueiredo, o Visconde de Ouro Preto, (1836-1912), para compor aquele que seria o último Ministério da Monarquia. A partir de então, Rui Barbosa passou a se articular à luz do dia com lideranças republicanas civis e militares. Para Cristian Lynch,

Quanto a Rui, monarquista até a véspera, o fato de não ser militar nem republicano histórico foi compensado pela ascendência sobre Deodoro, conseguida com seus prodigiosos conhecimentos administrativos e conservada com contínuas ameaças de abandonar o ministério. Rui tentou assim manobrar para que a ditadura fosse, dentro do possível, um breve interregno para a organização democrática e liberal da nova República. (LYNCH, 2007: 47-48)

Rui Barbosa considerava que a aliança com os militares era o preço a ser pago pela refundação institucional do Brasil, já que os "costumes naturais da população, corrompidos pela autocracia e pelo mandonismo", não seriam capazes de se autorregenerar no sentido do estabelecimento de uma democracia plena. Se para Rui Barbosa, a ditadura militar era o meio, a democracia liberal, como destaca Lynch, era o fim, era a utopia. A construção de novas instituições, de um novo regime político, teria efeito demiúrgico e inauguraria um ciclo virtuoso capaz de estabelecer no Brasil o "império das liberdades individuais". As novas instituições ensejariam melhores costumes políticos que, por sua vez, fortaleceriam as novas instituições.

Rui Barbosa teve êxito nas disputas internas ao governo provisório, onde enfrentou, e venceu, os militares positivistas que desejavam imprimir um perfil mais autoritário à República. Há o dedo de Rui Barbosa em todos os atos jurídicos que desenharam institucionalmente o novo regime. Em 15 de novembro, o governo provisório promulgou o decreto $n^{\circ} 1$, que instaurava o regime republicano federativo do governo. Rui Barbosa viu tornar-se realidade a federação, o fortalecimento dos poderes locais, que foi por décadas um dos seus principais projetos reformistas. Até o decreto $n^{\circ} 29$, que regulou a formação da comissão responsável por elaborar o projeto constitucional que seria submetido à apreciação da Assembleia Nacional Constituinte, foram 28 textos que, entre outras coisas, instituíram o Estado laico, o casamento civil e a eleição direta, medidas que Rui Barbosa defendia desde os anos 1870. A constituição promulgada em fevereiro de 1891 coroaria a vitória de Rui Barbosa. Finalmente, o jurista baiano viu seu projeto de nação ganhar formato institucional.

Rui melhorou os dispositivos referentes à intervenção federal, para permitir que os poderes judiciários e legislativos dos Estados pudessem requisitá-la, e a do Estado de sítio, frisando a necessidade de que o Congresso Nacional fiscalizasse os atos do governo. [...] o controle da constitucionalidade foi Rui quem enxertou no capítulo do Poder Judiciário, quase todo reescrito. O jurista baiano foi também o responsável por incluir na Constituição a inviolabilidade parlamentar e a ampliação da declaração de direitos, evitando que ela fosse inferior à da Constituição de 1824. (LYNCH, 2007: 51)

O doce sabor da vitória durou pouco e logo deu lugar ao gosto amargo da frustração. A instabilidade que acompanhava a República desde seu berço ganhou ares de Guerra Civil no final de 1891, quando Deodoro da Fonseca renunciou em favor de seu vice, Floriano Peixoto (1839-1895), também Marechal do Exército. A ditatura militar que até então se 
Rodrigo Perez Oliveira

apresentava como governo provisório assumiu o formato de regime político, com os militares manifestando de forma clara que tinham planos para o Brasil que em nada se assemelhavam à utopia liberal de Rui Barbosa. Após a chegada de Floriano Peixoto à Presidência da República, cada vez mais as instituições idealizadas por Rui Barbosa tornaram-se letra morta sem correspondência na realidade. Rui Barbosa saiu do governo e se tornou oposição. Mas como explicar o insucesso da República? As instituições que Rui Barbosa tanto cultuava não foram capazes de cumprir sua vocação demiúrgica. Por que?

Para Rui Barbosa, a culpa não era das instituições e sim do "terreno despreparado para receber fruto tão elevado" (BARBOSA, 1892: 166). A explicação para o fracasso da República liberal era o próprio Brasil, pois "não basta a emulação de instituições virtuosas se os costumes estão corrompidos" (IDEM). Aqui fica muito claro como a acusação de formalismo jurídico feita pelos conservadores foi, no mínimo, exagerada. Rui Barbosa tinha plena consciência de que, por si só, a importação de instituições não seria capaz de regenerar o Brasil, o que ele deixou claro já nos debates constitucionais, quando condicionou o sucesso do novo regime a um "amplo esforço de educação cívica da população e dos dirigentes políticos". Essa educação cívica, por sua vez, deveria ser conduzida por um "legislador virtuoso" cujo modelo seria ele mesmo, o próprio Rui Barbosa. É na atuação de Rui Barbosa como legislador original da República que podemos perceber os contornos mais sólidos do bacharelismo interventor. O bacharel interventor é representado como moralmente superior tanto ao homem comum, definido como ignorante e incapaz de conduzir sua própria vida, como ao político profissional, visto como naturalmente corrupto e corruptor. Volto ao assunto na última seção, quando examino especificamente esse tal bacharelismo interventor. Por ora, é o momento de dedicar alguma atenção ao colapso da IV República e à figura de Rodrigo Janot.

\title{
2.0. Rodrigo Janot e o colapso da IV República
}

\begin{abstract}
Deste novo quadro de referimento resultam consequências novas com relevância para o direito. Quando o Estado atua ou deixa de atuar lá onde tem obrigação de fazê-lo, enseja o controle jurisdicional de seus próprios atos e produz uma transferência maciça de competências para o mundo jurídico, por provocação, entre outros, do Ministério Público. Tal situação poderia ser definida como a judicialização das políticas públicas. (BARROS, 1996: 116)
\end{abstract}

Os estudiosos que estão se debruçando sobre o colapso da IV República destacam o "ativismo político do judiciário" como uma das principais características da crise em curso no Brasil. A tese do "ativismo político do judiciário" vem sendo interpretada de diferentes formas na bibliografia. Operando com a noção de "golpe parlamentar" para qualificar o impedimento de Dilma Rousseff, em 2016, Wanderley Guilherme dos Santos afirma que o "ativismo político do judiciário" não deve ser visto como um fenômeno "estranho à democracia" (SANTOS, 2017: 32). Em experiências de golpe parlamentar (Santos destaca os casos do Paraguai, da Finlândia e do Brasil), a semente do golpismo já estaria sendo cultivada na normalidade democrática. O autor localiza na Ação Penal 470, de 2005, 0 momento em que foi forjada a aliança entre lideranças do poder judiciário e a mídia hegemônica que onze anos mais tarde golpearia Rousseff. Lendo o fenômeno do ativismo do judiciário em perspectiva gramsciana, Felipe Demier e Demian Melo propõem a noção de "cesarismo togado" para iluminar aquele que, segundo os autores, é o aspecto definidor da "crise orgânica brasileira": a autonomização das instituições do Estado, que passam a funcionar de acordo com seus próprios interesses corporativos. Já Christian Lynch fala em uma "revolução judicialista" que teria começado nos anos 1990 como um "fenômeno 
Rodrigo Perez Oliveira

doutrinário-ideológico" e se aprofundado na década seguinte. A pista lançada por Lynch ajuda a compreender melhor a citação que serve como epígrafe a esta seção, onde podemos encontrar Rodrigo Janot palestrando na Conferência Nacional da Ordem dos Advogados do Brasil (OAB), em 1996. Na época, Janot era Presidente da Associação Nacional dos Procuradores da República (ANPR) e externou, sem meias palavras, aquela que na sua percepção deveria ser a missão do Ministério Público: intervir diretamente na sociedade, judicializando a política.
Justa [a judicialização da política] porque acompanhamos [o Ministério Público] de perto e vivenciamos toda a dinâmica do processo social, a instituição deve ampliar e especializar as suas atividades para que possamos, cada vez mais, buscando a plena realização da ordem jurídica, enfrentar situações que fazem do nosso país, às vésperas do terceiro milênio, um exemplo vergonhoso quanto aos indicadores sociais, a despeito de suas notáveis potencialidades de desenvolvimento econômico e social. (IDEM: 113-114)

Falando para uma plateia formada por advogados, Janot disse que o funcionário do MP não era um "servidor público qualquer", mas sim alguém vocacionado para "colaborar, mais do que qualquer outro, para o progresso e para a modernização da nação, para a superação do atraso atávico que bloqueia o desenvolvimento do Brasil" (IDEM). Mas não seria muita pretensão? A judicialização da política não poderia resultar numa espécie de tirania comandada por funcionários concursados? O próprio Janot responde.
A questão correta a ser colocada, portanto, não é a da politização da atuação institucional do Ministério Público e do próprio judiciário, mas a da judicialização de questões que, antes de um passado relativamente recente, eram tidas de caráter exclusivamente político, insuscetíveis de controle jurisdicional. (IDEM: p. 116)

Janot está questionando a autonomia do campo político em funcionar sem controle jurisdicional. $\mathrm{O}$ voto que o eleitor deposita periodicamente na urna não seria suficiente para garantir a transferência de soberania do representado para o representante. Isso aconteceria porque "em um país como o Brasil, maculado por um atraso crônico, o homem comum não tem plena consciência de suas próprias necessidades". O voto não seria capaz de vocalizar a vontade do eleitor porque o eleitor, simplesmente, não estaria plenamente capacitado para saber quais são as suas reais necessidades, precisando, portanto, de um tutor. É essa função que, segundo Janot, o "novo Ministério Público, autorizado pela constituição de 1988", deveria cumprir. Nas palavras do próprio Janot: "a intervenção judicial, ou judicialização da política enseja o exercício pleno da cidadania, como o corolário da democracia participativa, na medida em que permite a inclusão da coletividade na discussão de problemas sociais relevantes" (IDEM). O MP estaria mais qualificado que o político eleito para representar os interesses do povo. ${ }^{1}$

Se o debate a respeito do ativismo político do judiciário já estava sendo feito na década de 1990, foi em 2005, na ocasião da "crise do mensalão", que a questão entrou, de vez, na agenda nacional. Joaquim Barbosa (1954), então Presidente do STF e responsável pelo julgamento da Ação Penal 470, se transformou em fenômeno midiático. Apesar de grave, a crise do mensalão não impediu a reeleição de Lula, em 2006. O "ativismo judiciário" hibernou, podemos dizer, para acordar com toda força em março de 2014, quando, pra 
Rodrigo Perez Oliveira

utilizar outra vez as palavras de Christian Lynch, a "revolução judicialista" ganhou corpo na Operação Lava Jato. O sucesso político-midiático da Operação Lava Jato não seria tão grande se já não tivesse em curso o colapso do regime político que foi criado na experiência da redemocratização, e que durante muito tempo chamamos de "Nova República". Esse colapso começou a ser sentido coletivamente em junho de 2013. A partir desse momento, a ideia de que os políticos profissionais não eram capazes de representar os interesses da sociedade civil se tornou cada vez mais hegemônica, podendo ser resumida na máxima "não me representa", entoada nas manifestações promovidas nas principais capitais do Brasil.

As "jornadas de junho de 2013" são objeto de acaloradas disputas interpretativas. Jessé de Souza aponta a existência de uma relação de causa e efeito entre junho de 2013 e o impedimento de Dilma Rousseff, que o autor, a exemplo de Wanderley Guilherme dos Santos, também qualifica como um golpe parlamentar.
Na verdade, [as manifestações de junho de 2013] representam o início do cerco ideológico até hoje mal compreendido pela enorme maioria da população. A grande questão é como protestos localizados com foco em políticas municipais foram manipulados de tal modo a se "federalizarem" e atingirem a popularidade da Presidenta Dilma, que àquela altura gozava dos mais altos índices de aprovação no seu governo. (SOUZA, 2016: 86)

Ruy Braga propõe uma interpretação distinta, que vocaliza as críticas daqueles que durante o período dos governos petistas se apresentaram como "oposição de esquerda". 0 autor acredita que junho de 2013 foi o resultado dos equívocos políticos dos governos petistas.

2013 assistiu a convergência espontânea entre a luta política do precariado urbano manifestando-se nas ruas em defesa dos seus direitos sociais e a luta econômica da classe trabalhadora mobilizada sindicalmente em defesa de melhores salários e condições de trabalho. Em outras palavras, a combinação dessas duas dimensões das lutas de classes no país terá atingido simultaneamente tanto o modelo de regulação quanto o regime de acumulação que sustentam a reprodução do atual modelo de desenvolvimento capitalista brasileiro, anunciando o colapso do lulismo como estratégia de pacificação social. (BRAGA, 2016: 71)

Onde Jessé de Souza vê manipulação midiática, Ruy Braga enxerga a revolta espontânea dos trabalhadores precarizados com a conciliação de classe promovida pelos governos petistas. André Singer divide as "jornadas" em dois momentos: primeiro, quando os protestos ainda estavam sendo organizados pelo Movimento Passe Livre (MPL), houve uma aliança entre as classes médias urbanas e o novo precariado, impulsionada por problemas típicos da vida nas grandes cidades, como trânsito caótico, violência e baixa qualidade nos serviços públicos. Esse cenário teria dado origem a uma "situação de malestar geral", que aglutinou os manifestantes através de uma agenda negativa, o que explicaria o caráter fluído das "jornadas", que desde os primeiros momentos não apresentaram uma pauta programática mais clara. Já no segundo momento, após 18 de junho, a agenda das ruas passou a ser pautada por certo conservadorismo temperado com rejeição à política institucional. Em artigo recente, Daniel Pinha analisa aquilo que considera ser o "vocabulário político" de junho de 2013. Partindo das sugestões de Luís Felipe Miguel sobre as disputas semântico-políticas que envolvem as noções de "democracia" e "representação", Pinha argumenta que em junho de 2013 marcou as disputas pela "elasticidade" da democracia brasileira. 
Rodrigo Perez Oliveira

As Jornadas de Junho de 2013 canalizaram a crítica do conjunto da sociedade em relação às práticas políticas do modelo representativo, abrindo caminho para uma crise cujos desdobramentos ainda não são inteiramente conhecidos e cujos significados estão em disputa - e a multiplicidade de pautas favoreceu as disputas pela narrativa mais apropriada capaz de dar conta daqueles acontecimentos. Como um tribunal crítico, expôs o problema e abriu caminho para múltiplos desdobramentos e apropriações políticas, sem oferecer uma direção futura unívoca. (PINHA, 2018: 86)

Com todas essas divergências interpretativas, os autores, e outros estudiosos que já se dedicaram ao temaiv, concordam que o dia 02 de junho de 2013 marcou a inauguração das "jornadas". Foi neste dia, uma quinta-feira, que a Prefeitura de São Paulo, governada na época por Fernando Haddad, do Partido dos Trabalhadores, anunciou um aumento na tarifa dos transportes urbanos. Esse foi o gatilho para que o Movimento Passe Livre colocasse em curso um modus operandi que já caracterizava a atuação pública do grupo desde meados dos anos 2000: arregimentação de jovens universitários através de redes sociais, com a posterior organização de ocupações em espaços públicos estratégicos, com o objetivo de fortalecer a agenda de protestos e conquistar o apoio da sociedade civil. Em um trabalho específico sobre os movimentos sociais no Brasil contemporâneo, a socióloga Ilse Warren afirma que a pauta do MPL jamais se restringiu ao tema das tarifas dos transportes públicos, estando relacionada aos direitos dos cidadãos em uma perspectiva bastante ampliada, o que envolve "a mobilidade urbana de uma forma geral, que deveria ser considerada como um direito fundamental, tal como o direito à educação, à saúde". (SCHERER, 2012: 141)

Poucos meses depois do cataclismo político de junho, em setembro de 2013, Rodrigo Janot foi nomeado Procurador Geral da República pela Presidenta Dilma Rousseff. Já em dezembro de 2012, Janot iniciou sua campanha eleitoral, que tinha o objetivo de convencer seus pares, os outros procuradores da República, de que o seu projeto de Ministério Público era o mais adequado para a instituição e para o país. Na campanha, Janot repetiu os argumentos que vinha utilizando desde os anos 1990. Ao MP caberia a função de representar os interesses da sociedade civil, de falar em nome do "povo", como Janot deixou claro tanto na sabatina a que foi submetido no Senado, em 10 de setembro de 2013, como no seu discurso de posse, em 17 de setembro do mesmo ano. Nos dois momentos, Janot demonstrou estar atento aquilo que chamou de "clamor das ruas pela qualidade da representação política na democracia brasileira" e destacou o papel que a constituição de 1988 atribuiu ao MP: agir como o "genuíno representante do povo". No discurso de posse, Janot rememorou sua própria trajetória no MP.

Cheguei ao Ministério Público através de concurso público em 1984, quando a instituição já possuía o nome que tem hoje, mas cujo funcionamento foi profundamente alterado pela constituição de 1988. Naquele momento [1984] não havia autonomia. Havia, no entanto, esperança, pois a democracia ausente por muito tempo já não tardaria a voltar e traria consigo um Ministério Público profundamente renovado, um Ministério Público que se pautava na premissa de que sem o fortalecimento democrático não se faz justiça e sem justiça não há igualdade. (BARROS, 2013)

A constituições de 1988 é apontada por Janot como uma espécie de divisor de águas para a história do MP, como o momento de fundação do "novo Ministério Público". "O momento constituinte e a carta que dele resultou atribuíram necessário protagonismo ao 
Ministério Público, que passou o ser o primeiro juízo defensor da sociedade brasileira". A partir do segundo semestre de 2013, a crise da IV República só fez se agravar, o que fortaleceu a liderança de Rodrigo Janot. Na posição de principal responsável institucional pela Operação Lava Jato, Janot denunciou formalmente três Presidentes da República. Dilma e Lula foram denunciados quando já não estavam no cargo. Michel Temer foi denunciado duas vezes em pleno exercício de mandato. Até deixar a PGR, em julho de 2017, Janot foi um dos principais personagens daquilo que se convencionou chamar de "ativismo político do judiciário", junto com outras lideranças, como Luís Roberto Barroso, Ministro do STF, Sérgio Moro e Deltan Dallagnol, respectivamente, juiz e procurador responsáveis em primeira instância pela Operação Lava Jato. Mas de forma alguma devemos desconsiderar as especificidades que particularizam as atuações dessas lideranças. Rodrigo Janot, Luís Roberto Barroso, Sérgio Moro e Deltan Dallagnol não agiram da mesma maneira no cenário da crise. Barroso, na posição de Ministro efetivo do Tribunal Superior Eleitoral (TSE), votou pela impugnação da candidatura de Lula às eleições de presidenciais 2018, interferindo diretamente no resultado da corrida presidencialv. Sérgio Moro, em janeiro de 2019, foi nomeado Ministro da Justiça e Segurança Pública do governo de Jair Bolsonaro. Depois disso, Deltan Dallagnol se tornou a principal liderança da Operação Lava Jato, que na altura em que escrevo este artigo manifestou interesse em administrar um fundo com 1,3 bilhões de reais ${ }^{\text {vi }}$, o que causa estranhamento e incômodo em instâncias superiores do Poder Judiciário brasileiro, como o STF.

E Rodrigo Janot? Na última vez em que teve destaque no noticiário político, Janot declarou voto em Fernando Haddad no segundo turno das eleições presidenciais de 2018. Aquele que no comando da PGR protegeu institucionalmente a Operação Lava Jato e que, por isso, foi um dos principais responsáveis pela desestabilização do governo de Dilma Rousseff, veio a público no calor de uma disputa eleitoral para apoiar o petista Fernando Haddad. O que explica? Falar em "ativismo político do judiciário", em "revolução judicialista" ou em "cesarismo togado" não é o bastante. É necessário um conceito que dê conta das particularidades da liderança de Rodrigo Janot, que lance luz sobre a ancestralidade do tipo de pensamento político que prefigurou sua ação. É por isso que estou propondo neste texto o conceito "bacharelismo interventor".

\title{
3.0. Rui Barbosa e Rodrigo Janot: bacharéis interventores em tempos de crise
}

\begin{abstract}
O estudo do pensamento político- social foi capaz de formular ou de discriminar na evolução política e ideológica brasileira a existência de "estilos" determinados, formas de pensar extraordinariamente persistentes no tempo, modos intelectuais de se relacionar com a realidade que subsumem até mesmo os mais lídimos produtos da ciência institucionalizada, estabelecendo problemáticas e continuidades que permitem situar e pôr sob nova luz muita proposta política e muita análise científica atual. (BRANDÃO, 2005: 236)
\end{abstract}

O artigo seminal de Gildo Marçal Brandão é fonte de inspiração para a reflexão que estou desenvolvendo neste texto. $\mathrm{O}$ autor afirma que existem "formas de pensar" que "extraordinariamente" conseguem sobreviver na longa temporalidade, tornando-se uma espécie de gramática capaz de prefigurar comportamentos políticos. Essa sobrevivência não significa a simples permanência no tempo, como se as "grandes constelações de ideias" fossem preservadas por alguma força de natureza meta-histórica. Trata-se de uma sobrevivência que pode ser explicada pela identificação de um padrão de respostas recorrentes em situações históricas semelhantes. Partindo da sugestão de Gildo Brandão, 
Rodrigo Perez Oliveira

acredito que as atuações de Rui Barbosa e Rodrigo Janot em suas respectivas experiências de crise sinalizam a sobrevivência de um tipo de pensamento político. Quando as instituições estabelecidas estavam desmoronando, os dois personagens apresentaram respostas semelhantes. Em síntese, eles argumentaram que a refundação institucional do Brasil deveria ser feita através da importação de dispositivos pertencentes ao repertório institucional dos EUA. A importação, no entanto, não significava simples transplante, mas sim todo um esforço de adaptação que deveria ser coordenado pelo "jurista ilustrado", nas palavras de Rui Barbosa, ou pelo "promotor do Ministério Público", como disse Rodrigo Janot. Caberia ao bacharel interventor a adequação das instituições à realidade nacional, partindo sempre da premissa de que a lei virtuosa não deve apenas normatizar o convívio social, mas também servir como potência pedagógica capaz de regenerar costumes corrompidos.

Nos primeiros anos do século XX, Rui Barbosa dedicou suas energias intelectuais e políticas para explicar por que as instituições liberais fracassaram no Brasil. Já na década de 1990, Rodrigo Janot perguntava por que, apesar dos avanços promovidos pela constituição de 1988, o Brasil parecia ainda não ter alcançado a verdadeira democracia representativa.

Nós trouxemos todas as belezas das instituições americanas, naquilo que elas têm de mais precioso, para o Brasil. E que é o a que, presentemente, estamos assistindo? (...) Podeis dizer, Sr. Presidente, se os frutos correspondem às nossas esperanças? Podeis dizer se essas instituições tiveram, em nosso país, a grandeza dos seus resultados? Não, Sr. Presidente. E por que? (BARBOSA, 1966: 76-78)

São notórios e inegáveis os avanços promovidos pela constituição de 1988. Notória também é a nossa dificuldade em fazer viva a letra da lei. Por isso, pergunto aos senhores e senhoras advogados aqui reunidos: por que, no Brasil, o progresso constitucional ainda não se reverberou em progresso nos costumes e hábitos políticos? (BARROS, 1996: 15).

Os dois denunciam o não cumprimento de uma promessa institucional. Instituições consideradas avançadas e virtuosas não se mostraram capazes de estabelecer na realidade relações políticas avançadas e virtuosas. Por que? O que teria faltado? O que precisava ser feito? É na forma como Rui Barbosa e Rodrigo Janot responderam essas perguntas que identifico aquilo que estou chamando desde o início do texto de "bacharelismo interventor". Para Rui Barbosa, o problema não estava nas instituições, mas sim na realidade que as abrigou. Em discurso no Senado realizado em 1903, ele apresentou seu diagnóstico. Era fato assumido pelo legislador original da República que a constituição liberal não impediu a implementação de uma tirania militar no governo de Floriano Peixoto. "Por culpa dos executores do regime? Não. Por culpa das instituições adotadas? Também não" (BARBOSA, 1966, p. 76).

Na defesa do formalismo constitucional republicano, o que na prática significava uma defesa de si mesmo, Rui Barbosa atribuiu o fracasso da República aos "hábitos políticos brasileiros", segundo ele "maculados pela escravidão, pelo mandonismo e por toda sorte de violência". Mas não podemos confundir essa defesa do formalismo constitucional com o argumento da inadequação das instituições liberais à realidade nacional. Esse era o argumento dos detratores de Rui Barbosa, que acreditavam que os costumes são anteriores às instituições e que, por isso, as instituições devem ser moldadas a partir dos costumes. A lógica de Rui era diametralmente oposta: as instituições liberais eram, sim, capazes de regenerar costumes corrompidos, mas isso não aconteceria do dia para noite, em um passe 
Rodrigo Perez Oliveira

de mágica. Era necessário dar tempo às instituições, protegê-las, e investir na "educação cívica do povo". O Brasil ainda não estava pronto para realizar plenamente "as leis que maravilharam o mundo moderno" (IDEM), mas isso poderia ser corrigido com o tempo, "se as classes conservadoras tomarem para si a nobre função de preparar o espírito bruto do povo para acolher os princípios fundadores da liberdade moderna" (IDEM, p. 77).

Em meados dos anos 1990, Rodrigo Janot disse que era necessário um "maior protagonismo para o MP, o que ainda não se tornou realidade, apesar dos preceitos estabelecidos na constituição" (BARROS, 1996, p. 15). Foi somente em julho de 2017, quando fez a avaliação de sua gestão à frente do PGR em entrevista concedida ao jornalista Roberto D'Avila, que Janot formulou com clareza o que faltava nos anos 1990 e que, agora, na segunda década do século XXI, não faltava mais: "hoje, o MP tem instrumentos jurídicos para cumprir sua missão institucional (BARROS, 2017). Janot estava se referindo à lei 12.850, assinada por Dilma Rousseff em 2013, que regulamentou a "delação premiada" no Brasil, concluindo a incorporação da colaboração penal ao direito brasileiro, o que aconteceu em um longo processo jurídico iniciado em 1990, com a lei 8.072. "A lei 12.850, finalmente, pôs fim ao imbróglio que se arrastava desde os anos 1990, normatizando procedimentos e dando segurança jurídica às provas coletas através da colaboração penal", disse Janot em conferência pronunciada nos EUA e já citada anteriormente.

Rui Barbosa condicionou o sucesso das instituições norte-americanas implementadas no Brasil pela constituição de 1891 à mediação de setores ilustrados da sociedade, as "classes conservadores", entre as quais estavam os "profundos conhecedores dos negócios da lei". Para Rodrigo Janot, aquilo que ele considerava ser a plena realização do projeto de MP desenhado na constituição de 1988 se devia à importação de um preceito jurídico norteamericano. Os projetos regeneradores são diferentes, mas o diagnóstico da realidade e a importância atribuída ao bacharel interventor são bem parecidos.

Urge fundar, na República, a liberdade, que a Constituição republicana Ihe deu, e os governos republicanos Ihe tiraram. Um erro vulgar enxerga exclusivamente na autoridade a essência do princípio conservador. Há, porém, um elemento não menos essencial à conservação dos Estados: a liberdade. A democracia conservadora, opondo-se à opressão e à licença, faz-se, a um tempo, de autoridade e liberdade. (...) Entre a constituição republicana e sua efetiva implementação na realidade estão as classes conservadoras brasileiras que devem preparar o terreno e inocular no povo o apreço pela liberdade (BARBOSA, 1952: 33).

Havia, porém, esperança daqueles que singravam aqueles mares revoltos. A democracia, então ausente por demasiado tempo, já não tardaria a voltar e traria consigo um Ministério Público profundamente renovado: um Ministério Público construído com base na noção fundamental de que, sem o fortalecimento democrático, não se faz justiça, sem justiça não há igualdade e, sem igualdade substantiva, não há como vicejar o desenvolvimento pessoal, social e econômico. Dependia de nós, então jovens procuradores da República, a missão de concretizar a relevância institucional do Ministério Público que nascia. Pusemos, então, mãos à obra. Lutamos durante toda a década de 1990 pelo fortalecimento real e não apenas formal de nossa instituição. Agora aguardamos com ansiedade a aprovação da lei que oficializa a colaboração penal, instituto presente no Direitos dos EUA e até então ausente entre nós. Munido dessa lei, o MP terá segurança jurídica para exercer integralmente suas atribuições e 
Rodrigo Perez Oliveira

ajudar o Brasil a caminhar rumo à democracia representativa plena.

(BARROS, 2013)

Por mais que as instituições em questão fossem dignas de elogio, sozinhas elas não eram capazes de operar milagres. Era necessário algo mais, uma potência capaz de mediar a relação da lei virtuosa com a realidade de modo a "fazer penetrar a jurisdição no coração e na alma do povo" (BARBOSA, 1952, p. 34), como disse Rui Barbosa em palestra no teatro Polyteama, em São Paulo, realizada em outubro de 1902. Na avaliação de Rui Barbosa e Rodrigo Janot, o povo brasileiro ainda não estava preparado para se fazer representar e, por isso, a política sofria de um vício de origem. Diante de um povo despreparado, o político eleito representava apenas seus próprios interesses. Rui Barbosa e Rodrigo Janot desconfiaram dos políticos profissionais. Rui responsabilizou o governo, a política, por ter tirado da nação a liberdade que a constituição lhe dera. Janot confrontou a classe política, independente do partido político. Na sabatina de sua recondução à PGR, realizada na Comissão de Constituição de Justiça do Senado Federal em 26 de agosto de 2015, Janot conclamou os parlamentares a liderarem a nação na "travessia da tempestade, cumprindo a mais nobre das funções na democracia moderna: a representação política". A "tempestade" a que Janot se referia era a crise política, bastante aguda naquela altura, quando a possibilidade do impedimento da Presidenta Dilma já era uma realidade.

Ao longo de doze horas, Janot foi sabatinado pelos Senadores, protagonizando momentos de tensão com Fernando Collor de Mello (PTC/AL) e com parlamentares da bancada do PSDB, então oposição a Dilma Rousseff, que insistiam na tese de que a PGR deveria denunciar a mandatária por crime de responsabilidade na matéria das "pedaladas fiscais"vii. Janot respondeu a todos (Aécio Neves, Aloísio Nunes e Álvaro Dias), afirmando, com contundência, que a "PGR age motivava por questões técnicas e não políticas", e que "o MP não pode se deixar levar por conflitos políticos que em nada representam os reais interesses da nação", concluindo que "ainda não há evidências técnicas que justifiquem o denunciamento da Presidente da República. Por isso não o fiz, o que não significa que não farei caso seja reconduzido ao cargo que hoje ocupo" (BARROS, 2015). Fica a sensação de que Janot nutria certo desprezo pelos políticos reunidos naquela casa legislativa, ainda que a liturgia do cargo e o interesse de ser aprovado na sabatina tenham disciplinado seu discurso. Talvez por esse desprezo nutrido à totalidade da classe política, o ativismo de Janot não tenha reconhecido especificidades partidárias. Em algum momento da crise da IV República, a flecha de Janot acertou no PMDB, no PT, no PSDB, no DEM, na época os principais partidos do sistema político brasileiro. Diante da percepção da baixa qualidade da classe política, qual seria a solução para o Brasil? Rui Barbosa e Rodrigo Janot propuseram uma intervenção saneadora sobre a realidade. $O$ interventor deveria ser o estudioso da lei, 0 conhecedor da legislação, o bacharel. Dado o despreparo do povo para fazer representar seus interesses de forma consciente e autônoma, a autoridade do bacharel interventor não poderia estar fundada no voto, mas sim na competência técnica.

Depois da desilusão provocada pela Ditadura florianista, Rui Barbosa reorientou as diretrizes do seu pensamento reformista, propondo uma restrição temporária à soberania popular através da ideia de "classes conservadoras". Já que o povo não era capaz de zelar pelas liberdades democráticas e parecia "alimentar e gostar da tirania", a soberania popular deveria ser limitada, pelo menos em um primeiro momento, ficando restrita aos "grupos sociais ilustrados e preparados para a vida ativa" (BARBOSA, 1952: 31). A inflexão programática de Rui não passou despercebida pelos seus críticos. Afonso Celso denunciou a mudança no comportamento político de Rui Barbosa em artigo ironicamente intitulado "Vindas e idas", publicado no "Jornal do Comércio" em novembro de 1894. 
Rodrigo Perez Oliveira

Por vinte anos, o sr Rui Barbosa esbravejou no parlamento brasileiro em defesa das reformas nas instituições monárquicas. $\mathrm{O}$ orador defenestrava o sistema eleitoral, exigia eleições diretas, dizia que o povo deveria ser chamado a escolher soberanamente seus governantes. E agora, na República, Rui Barbosa convoca as classes conservadores para amparar a representação política. Não é isso uma eleição indireta? (FIGUEIREDO, 1895).

Afonso Celso acusou também a mudança de posição de Rui Barbosa no que se refere às relações entre o Estado e a religião. "O mesmo homem que defendeu com unhas e dentes a desvinculação do Estado com a santa igreja, hoje diz que a religião cristã é condição para a regeneração dos costumes políticos" (IDEM). O político monarquista que, como já sabemos, foi rejeitado por Rui Barbosa na ocasião da formação do último governo da Monarquia, veio a público cobrar coerência do homem que deu ares de legitimidade ao movimento militar que derrubou o trono de Pedro II. Ao pedir eleição direta, Rui Barbosa acusou a Monarquia de sufocar o direito do povo à representação política. Ao defender o Estado laico, Rui Barbosa definiu a religião como assunto de foro íntimo. Agora que a Monarquia estava abolida e que a República liberal havia se degenerado em ditadura militar, Rui Barbosa revisava suas teses reformistas, apontando a incapacidade do povo brasileiro para a eleição direta e destacando o papel do catolicismo para a correção de costumes políticos corrompidos. Já que as teses que fundaram o reformismo barbosiano nas últimas décadas de Monarquia e que, em última instância, o levaram a aderir à República, foram desmentidas pela realidade, "não seria mais adequado restaurar a Monarquia?", pergunta Afonso Celso. Rui Barbosa não fugiu ao debate e respondeu às provocações de seu adversário no artigo "Minhas Conversões", também publicado no "Jornal do Comércio".

Sob a República atual, as nossas liberdades são incomparavelmente inferiores às que nos restavam sob a Monarquia. (...) já não é mais tempo de restaurar a Monarquia, mas sim de regenerar a República, principalmente porque a desgraça da tirania militar não tem nada com o caráter das instituições: é simplesmente o efeito do domínio da espada. (BARBOSA, 1895)

Ao elogiar abertamente a Monarquia, Rui Babosa, pela primeira vez, ensaiou algo próximo a um mea culpa. É como se ele estive dizendo que, tal como se apresentaram na realidade brasileira, o governo coroado era superior à República, mesmo que instituições republicanas fossem melhores que as instituições monárquicas. Não bastava, contudo, a superioridade formal. Era necessária, também, a superioridade política manifestada na prática, na realidade. Por isso, naquele momento, ainda sob o trauma da ditadura florianista, Rui Barbosa afirmou a superioridade da Monarquia sobre a República. Mas como a República era fato consumado, a restauração da Monarquia já não era possível. A única esperança estava na possibilidade de reconstrução da República, fazendo acontecer na realidade as virtudes das instituições liberais. Para isso, seria necessário um período de transição, de preparo.

Nada mudei em essência, ainda continuo defendendo a eleição direta e a separação entre Estado e religião. Foi a realidade que mostrou que o Brasil ainda não está pronto para receber tão elevados valores. Não está pronto hoje. Quem sabe amanhã! (...) Até que o povo esteja pronto, seu destino político deve ser dirigido pelas classes conservadoras, seus valores e temores regidos pela religião e pela fé. (BARBOSA, 1895) 
Rodrigo Perez Oliveira

A direção política das classes conservadores e a religião, portanto, não eram um fim em si, mas meios para alcançar a tão sonhada utopia liberal. Como vimos há pouco, Rui Barbosa tinha usado argumento semelhante anos antes, quando justificou sua participação no governo provisório de Deodoro da Fonseca. Da religião católica, Rui Barbosa esperava uma potência moralizante capaz de disciplinar o povo no respeito às autoridades e a padrões "civilizados" de certo e errado.

Não é a soberania do povo o que salva as Repúblicas. Não são as urnas eleitorais que melhoram os governos. [...] A soberania do povo constitui apenas uma força, a grande força moderna, entre as nações embebidas na justa aspiração de se regenerarem a si mesmas. Mas essa força popular há mister dirigida por uma alta moralidade social. As eleições mudam os Governos, mas não os reformam. As liberdades políticas não têm por objeto satisfazer a vaidade dos cidadãos, entregando-lhes o cetro do poder. O verdadeiro destino dessas liberdades está em revestirem e abroquelarem as liberdades civis, isto é, os direitos da consciência, da família e da propriedade. Essas três categorias de direitos ancoram na palavra divina, a saber, na divina constituição do homem. Mas só os povos religiosos os têm definido e praticado seriamente, ao menos no que respeita à consciência e à família. (BARBOSA, 1956: 382).

Para Rui, "democracia" era muito mais do que o direito ao voto, pois a depender do preparo intelectual e dos qualificativos morais de quem se coloca diante da urna, o voto poderia ser pouca coisa além de moeda de troca para atender necessidades imediatas e ambições de líderes inescrupulosos. Para que o voto tivesse valor político, para que fosse, de fato, o símbolo da "liberdade moderna", o eleitor precisava estar preparado para "reconhecer na autoridade o princípio maior de organização da vida" e não apenas "a espada a impor pela força a ordem da violência". Era, justamente, no "preparo" desse eleitor que o catolicismo, para Rui, poderia desempenhar uma função estratégica, na medida em que "o sentimento católico, quando é puro, instrui na obediência à autoridade nobre e eivada de bons sentimentos". Direto ao ponto: para Rui Barbosa, o catolicismo era estratégico porque poderia ensinar o povo brasileiro a obedecer, a respeitar a autoridade das lideranças que deveriam conduzir a implementação das instituições liberais na realidade nacional. Rui Barbosa chamou de "classes conservadoras" aqueles que, "pela virtude e pelo senso de patriotismo", faziam por merecer a obediência do povo. A amplitude do conceito de "classes conservadoras" foi aumentando com o tempo, como demonstra Flavia Maria Rê, autora de um importante estudo sobre o pensamento político de Rui Barbosa. Em meados da década de 1890, quando Rui ainda estava muito impactado pelo trauma da ditadura florianista, as classes conservadoras eram formadas, basicamente, pela "classe proprietária e produtiva" e pelos "iniciados nas ciências das leis". Na ocasião de sua segunda campanha presidencial, em 1919, quando discursou na Associação Comercial do Rio de Janeiro, Rui Barbosa foi mais generoso.

Não é só o proprietário, o industrial, o comerciante. Não é somente o banqueiro, o armador, o fabricante, o senhor de latifúndios, o dono de minas e estradas. Não. [...] Grave erro seria o de pormos a uma parte o operário, a outra as classes conservadoras. Nas classes conservadoras, ao lado do patrão, está, com o mesmo direito, o obreiro. Os elementos conservadores da sociedade são o trabalho, este primeiro que todos, o trabalho, digo, o capital, a ciência e a lei, mantida pela justiça e pela força. Isto é: a lavoura, a indústria, o comércio, a instrução, a magistratura e as forças armadas. Eis, 
Rodrigo Perez Oliveira

senhores, verdadeiramente, as classes conservadoras. (BARBOSA, 1919: 54)

Os profissionais da lei estão presentes nas duas definições. Na pena de Rui Barbosa, o conhecedor da lei não era apenas um juiz, um promotor, ou um advogado. Não era, tão somente, um profissional. Era, sobretudo, um pedagogo, uma liderança social que tinha a missão de "difundir os valores democráticos e liberais no seio do povo" e "fazer ecoar a voz da justiça e do direito quando a voz do povo não for capaz de se fazer ouvida". O bacharel, em virtude do seu conhecimento da lei, sabia o que era bom para o povo, o que deveria ser feito para libertar o povo. E sabia, naturalmente, melhor que o próprio povo. $\mathrm{O}$ argumento apresentado por Rodrigo Janot é muito parecido. Em seus dois discursos de posse, realizados em setembro de 2013 e em setembro de 2015, Janot falou sobre o lugar do Ministério Público no projeto de consolidação plena da democracia representativa no Brasil.

Desde a década de 1990, os procuradores do Ministério Público trabalharam arduamente para o cumprimento do ordenamento institucional. Com alguns percalços, vencemos a batalha e colaboramos para inegável progresso que marca os últimos anos da história do Brasil. Hoje, o poder público mais cauteloso na gestão daquilo que é de todos, mais cuidadoso na hora de contratar serviços, empresas públicas e privadas comprometidas com os direitos dos deficientes e o combate diurno à corrupção e à impunidade. (...). Como bem disse Trancredo Neves, a cidadania não é um comportamento passivo, de espero, mas sim uma postura altiva, de busca. Não tenho dúvidas de que o MP está vocacionado para conduzir o povo brasileiro nessa busca. (JANOT, 2013)

Iniciando hoje minha segunda gestão à frente da PGR, tenho o objetivo de dar continuidade ao fortalecimento do Ministério Público, que se faz ainda mais necessário num momento de tempestade. A corporação trabalhou muito e vai continuar trabalhando para colaborar com o aprimoramento da representação política no Brasil. (JANOT, 2015).

Nas duas ocasiões, Janot estava ao lado de Dilma Rousseff. Na solenidade de 2013, Dilma e Janot apresentaram discursos protocolares, marcados por deferência recíproca. Nenhum dois mencionou os eventos de junho, que messes antes tinham sacudido a cena política nacional. Na ocasião, Janot se manteve próximo ao que tinha falado em 1996 no congresso da OAB. A intervenção do MP na política era legítima pois a corporação estava vocacionada a defender a sociedades até mesmo quando o povo não sabe que precisa ser defendido. Seria o MP o responsável por transformar o comportamento passivo típico da democracia precária, onde o eleitor apenas vota, em cidadania ativa, onde o cidadão, amparado e defendido pelo Ministério Público, é capaz de pautar o poder político, fazendo representar plenamente seus interesses. A situação foi bem diferente em 2015, quando a crise se apresentava de maneira inegável e dramática e as duas lideranças sabiam perfeitamente que aquele era o momento de disputar narrativas. Dilma era hostilizada nas ruas, criticada na imprensa e estava acuada por um processo de impeachment que cada vez mais ganhava força política. Janot era personagem conhecido por todo brasileiro minimamente atento à crônica política. A operação Lava Jato estava mais forte que nunca, tendo grande popularidade junto à opinião pública. A autoridades discursaram e, com a moderação que a solenidade exigia, disputaram, duelaram. Ambos reconheceram a importância do MP como "advogado do povo" e "defensor da sociedade". Também concordaram que a instituição havia se fortalecido no Brasil, mas apresentaram versões diferentes para explicar os motivos desse fortalecimento. Dilma disse que a nomeação de 
Janot significava a "convicção compartilhada desde 2003 [pelo governo do Partido dos Trabalhadores] de que um MP independente do poder instituído é fundamental para o aprimoramento da democracia. Esse será o mais importante legado que deixamos para o Brasil". Janot atribuiu o fortalecimento do MP aos "esforços empreendidos pelos homens e mulheres que formam nossa corporação". O mesmo embate aconteceu em relação à autoria da lei 12.850. "A assinatura da lei que oficializou a delação premiada é a prova maior do compromisso do meu governo com o combate à corrupção". Por seu lado, disse Janot que "a lei que incorporou a colaboração penal ao direito brasileiro foi o desfecho de uma longa luta empreendida pelos procuradores do MP desde a década de 1990". Os discursos foram encerrados, a ata da posse assinada. Janot e Dilma se cumprimentaram, posaram para as fotos e cada um saiu por um lado, levando junto a certeza de que os próximos meses seriam decisivos.

Rodrigo Janot iniciou seu segundo mandato à frente da PGR disposto a por em prática o "protagonismo do MP". Janot passou a ser personagem frequente no noticiário político, sendo aplaudido nos aeroportos, chegando a ser fotografado segurando um cartaz com as palavras "Janot, a esperança do Brasil". Seu nome foi cogitado para a sucessão presidencial, o que Janot sempre negou, dizendo que sua política "não poderia ser eleitoral, pois o voto não é a única forma de representar os interesses do povo". Tal como vimos Rui Barbosa fazer quando conclamou as "classes conservadoras" a salvarem a República, Janot apontou a insuficiência do voto para a representação política. Os dois afirmaram a importância de uma intervenção que se desse à revelia do rito eleitoral e que fosse efetivada por um bacharel, por um "iniciado nos negócios da lei", como disse Rui Barbosa. Janot foi mais específico ao dizer com clareza que o interventor ideal não seria qualquer profissional da lei. Deveria ser, especificamente, o Procurador do Ministério Público.

\section{Para concluir, um breve elogio ao anacronismo}

Em um ensaio bastante instigante e provocativo, a historiadora francesa Nicole Loraux elogiou o anacronismo, dando estatuto de possibilidade analítica ao que a comunidade dos historiadores profissionais costuma tratar como desvio metodológico. "O anacronismo é o pesadelo do historiador, o pecado capital contra o método, do qual basta apenas o nome para constituir uma acusação infamante" (LORAUX, 1992: 57 ). O método histórico nasceu como atividade científica no século XIX com o objetivo de compreender as especificidades dos fenômenos, de situar cada coisa no seu devido contexto histórico. Nessa perspectiva, o anacronismo representa o fracasso, a incompetência na operação do método. Toda essa preocupação em evitar o anacronismo, segundo Loraux, traz consigo o risco de "entravar" a reflexão histórica, "impedindo a audácia historiadora, ao contrário do que acontece com o antropólogo, que recorre sem perturbação de consciência à prática da analogia".

"Analogia". Foi exatamente isso que tentei fazer neste texto, ao propor uma relação de semelhança entre dois personagens tão diferentes e afastados no tempo por uma centena de anos. Se chegou até aqui, o leitor talvez esteja com aquela ruga de desconfiança formada na testa, lançando sobre mim a pecha do anacronismo. Por isso, numa última tentativa de deixar boa impressão, faço desta conclusão um exercício de justificativa, seguindo a trilha aberta por Nicole Loraux e tomando o anacronismo como possibilidade de análise história. $\mathrm{O}$ anacronismo somente é visto como o pecado capital do método por uma cultura histórica baseada na premissa de que o tempo é agente total das transformações, aquilo que Berbe Bervenage e Cris Lorenz chamaram de breaking up time historicista. Nesse sentido, o elogio ao anacronismo, obviamente, não significa desprezo ao método, mas sim uma outra forma de pensar o tempo histórico: 
Rodrigo Perez Oliveira

Por que fazer o elogio do anacronismo quando se é historiador, senão para sugerir que, no tempo cronológico da história, conviria prestar atenção ou, pelo menos, conceder um lugar a todos os fenômenos de repetição, sem garantia de nenhuma lição ou de nenhuma experiência? Se me fosse preciso definir mais exatamente essa forma particular de anacronismo que é a atenção ao repetitivo, eu adiantaria de bom grado que ela tem a ver com a consideração sistemática das paixões e da relação com o poder, que, provavelmente, aliás, são cumplices. (LORAUX, 1992: 67)

Loraux está dizendo que a história não se faz apenas de transformações, mas também de continuidades, de repetições, o que confere força analítica ao anacronismo e viabiliza o procedimento da analogia. Se a paixão pelo poder é constante na história, experiências afastadas no tempo guardam alguma semelhança entre si e, por isso, podem, e devem, ser aproximadas. Tanto Rui Barbosa como Rodrigo Janot agiram movidos por projetos de poder, foram alimentados por utopias: em Barbosa, a utopia era a democracia liberal. A utopia de Janot era a plena representação política. Ambos depositaram em instituições importadas dos EUA a esperança de ver a utopia realizada. Os dois construíram a imagem do bacharel interventor como um de herói cívico capaz de resolver os dilemas da nação. Janot e Barbosa tentaram tutelar a política. Os pontos de semelhança são muitos, o suficiente, acredito, para sugerir que entre um e outro há a sobrevivência de um pensamento político. Não sei se o bacharelismo interventor chega a ser uma "família intelectual", para utilizar o termo criado por Gildo Marçal Brandão. Para saber, seria necessário estudar outros profissionais do direito que ganharam notoriedade em experiencias de crise, o que não poderia ser feito nos limites deste artigo.

Minha pretensão aqui foi muito mais modesta. A bibliografia especializada está repleta de estudos que analisam a atuação política dos bacharéis em direito, algo que foi testemunhado ainda no século XIX, quando Joaquim Nabuco disse que as faculdades de direito eram a "antessala da câmara dos Deputados". O bacharelismo interventor é uma manifestação, entre outras tantas, desse ativismo político dos profissionais da lei. Da comparação entre Rui Barbosa e Rodrigo Janot fica, ao menos para mim, a sensação de que em momentos de profunda crise, algum bacharel descerá do seu olimpo, com o dedo em riste, para dizer que a culpa, na verdade, é do povo, que, vivendo em situação de eterna infância, precisa de um tutor.

(Recebido para publicação em janeiro de 2019)

(Reapresentado em fevereiro de 2019)

(Aprovado para publicação em maio de 2019)

\section{Cite este artigo}

OLIVEIRA, Rodrigo, 2019. O bacharelismo interventor no pensamento político brasileiro: uma abordagem comparativa entre Rui Barbosa e Rodrigo Janot. Revista Estudos Políticos: a publicação semestral do Laboratório de Estudos Hum(e)anos (UFF). Rio de Janeiro, Vol.10 | N.1, pp. 29-50, maio de 2019. 
Rodrigo Perez Oliveira

\section{Notas}

1. Segundo Sérgio Buarque de Holanda (2010), a crise política que derrubou, em 1868, o gabinete ministerial presidido por Zacarias de Góis e Vasconcelos e levou ao governo o gabinete presidido pelo Visconde de Itaboraí, inaugurou o cenário de desestabilização institucional que se arrastaria ao longo das décadas de 1870 e 1880, resultando no fim da Monarquia, em 1889. Nas palavras do autor: "A substituição do ministério, tal como foi feita, além de deixar claros o artifício e a burla em que todo o sistema assentava, dissipou as esperanças daqueles que achassem viável uma amálgama de elementos tão díspares. Apanhados de supetão pela extraordinária desenvoltura de que o rei se mostrou capaz, ao fazer o uso dos desmedidos poderes de que efetivamente dispunha, os [liberais] históricos e os progressistas renunciaram, ao menos no âmbito parlamentar, às suas divergências, para cerrarem fileira em volta do estadista que os caprichos de São Cristóvão acabavam de sacrificar tão duramente" (p.146).

2. Segundo o biógrafo Américo Jacobino Pamplona (1978), Rui Barbosa não estava em São Paulo na ocasião da publicação do Manifesto Republicano (1870), pois havia retornado para Salvador em 1869, com o título de bacharel na mala. Esse fato, somado aos vínculos de Rui Barbosa com liberais monarquistas baianos, impediram sua adesão à causa Republicana, o que somente aconteceria plenamente no final da década de 1880, nas vésperas da proclamação do novo regime.

3. No final da década de 1860, segundo Flávia Maria Rê (2006), Rui Barbosa estava muito marcado pelos escritos de Walter Bagehot (1826-1877), ensaísta inglês que na segunda metade do século XIX ganhou certa notoriedade ao analisar as instituições políticas britânicas, especialmente após o a "reform act", de 1867, que, entre outras coisas, instituiu eleições diretas na Inglaterra.

4. Marco Nobre (2013), Pablo Ortellado (2013), Lincon Secco (2013).

5. Em 22 de agosto de 2018 foi publicada pelo Instituto Datafolha a última pesquisa eleitoral em que o nome Lula aparecia entre os presidenciáveis. O petista liderava com $39 \%$ das intenções de voto, enquanto Jair Bolsonaro aparecia em segundo, com 19\%. Nas simulações de segundo turno, Lula aparece vencendo Bolsonaro por 20 pontos, num 52 a 32 . É claro que isso não quer dizer que Lula venceria a eleição, caso tivesse sua candidatura homologada. Porém, creio que poucos negarão que ele 
Rodrigo Perez Oliveira

seria um candidato competitivo. Nesse sentido, a impugnação de sua candidatura por Luís Roberto Barroso foi, sim, uma interferência importante na dinâmica eleitoral.

6. A partir de setembro de 2018 , a força tarefa da operação Lava Jato, formada por procuradores da República lotados em Curitiba (PR), propuseram a criação de um fundo com 1,3 bilhões de reais, pagos pela Petrobrás ao Brasil, como uma espécie de indenização pelos atos de corrupção cometidos pela empresa. A proposta do "Fundo Lava Jato" dividiu opiniões e foi rechaçado por lideranças do mundo jurídico, como o Ministro Gilmar Mendes, que na corte do STF usou palavras duras para qualificar aquilo que ele acreditar ser a formação de um "Estado paralelo". Após as críticas, a força tarefa da Lava Jato desistiu da criação do fundo.

7. No começo de setembro de 2015, os juristas Miguel Reale e Janaína Paschoal protocolaram na Câmara dos Deputados o pedido de impeachment de Dilma Rousseff, onde acusaram a Presidenta da República de crime de responsabilidade contra a lei das Responsabilidade Fiscal, as chamadas "pedaladas fiscais". O pedido foi acolhido por Eduardo Cunha, então Presidente da Câmara dos Deputados, em 02 de dezembro de 2015, tendo resultado no afastamento definitivo de Dilma Rousseff em 31 de agosto de 2016.

\section{Referências bibliográficas}

BARBOSA, Rui. O Estado de sítio: sua natureza, seus efeitos, seus limites. Rio de Janeiro: Companhia Impressora, 1892.

. Eleição Direta. In OCRB. Vol. II 1872-1874.

Tomo II. Rio de Janeiro: Ministério da Cultura; Fundação Casa de Rui Barbosa, 1987.

. O Partido Republicano Conservador. In OCRB. Vol. XXIV (1900-1904). Tomo I. Rio de Janeiro: Ministério da Educação e Saúde, 1952.

. Discurso no Colégio Anchieta. In OCRB. Vol. XXX. Tomo I. Rio de Janeiro: Ministério da Educação e Cultura, 1956.

- Escritos e discursos seletos. Rio de Janeiro: Companhia Aguilar Editora, 1966. . Minhas conversões. Jornal do Comércio, 23 de fevereiro de 1895.

Às classes conservadoras. In: Campanha presidencial (1919). Bahia: Livraria Catilina, 1919. 
FIGUEIREDO, Afonso Celso de Assis. Vindas e Idas. Jornal do Comércio, 17 de novembro de 1895.

BARROS, Rodrigo Janot Monteiro de. Palestra no Institute do Woodrow Wilson Center, em Washington, EUA. 17 de julho de 2014. https://www.youtube.com/watch?v=cqBOFQVv_Tw. Consultado em 26 de março de 2019. - Limites à atuação do Ministério Público. In: Conferência Nacional da Ordem dos Advogados do Brasil, 16., 1996, Brasília. Anais ... Brasília: OAB, Conselho Federal, 1996. p. 113-116.

. Discurso de posse para o primeiro mandato na Procuradoria Geral da República. https://www.youtube.com/watch?v=389DMDYU1pc. Consultado em 23 de março de 2019. . Entrevista concedida a Roberto D'Avilla, em 03 de julho de 2017. http://g1.globo.com/globonews/roberto-davila/videos/v/roberto-davila-entrevistarodrigo-janot-quarta-5-as-23h/5981177/. Consultado em 02 de abril de 2019.

. Sabatina de recondução à PGR, realizada na $\mathrm{CCJ}$ do Senado Federal em 25 de agosto de 2015. https://www.youtube.com/watch?v=UtshfCi8tHI.

Consultado em 02 de abril de 2019.

PRADO, Eduardo. Fastos da ditadura militar brasileira. São Paulo: Martins Fontes, 2003.

ALBUQUERQUE, Wlamyra R. "É a paga!" Rui Barbosa, os capangas e a herança abolicionista (1889-1919). In GOMES, Flávio; DOMINGUES, Petrônio (org.). Experiências da emancipação. Biografias, instituições e movimentos sociais no pós-abolição (1890-1980). São Paulo: Selo Negro, 2011.

ADORNO, Sérgio. Os aprendizes do poder: o bacharelismo liberal na política brasileira. Rio de Janeiro: Paz e Terra, 1988.

BRAGA, Ruy. Terra em Transe: o fim do lulismo e o retorno da luta de classes. In. LOUREIRO, Isabel; SINGER, André (ORGS). As contradições do lulismo. São Paulo: Boitempo, 2016. pp. 55-92.

BRANDÃO, Gildo Marçal. Linhagens do pensamento político brasileiro. Dados. Revista de Ciências Sociais, Rio de Janeiro, vol. 48, $n^{\circ}$ 02, 2005. pp. 231-269.

BEVERNAGE, Berber. LORENZ, Chris. Breaking up time: Negotiating the borders between Present, Past and Future. Storia della Storiograia, $63 \cdot 1 / 2013$.

DEMIER, Felipe; MELO, Demian. Onda conservadora, crise orgânica e cesarismo. In: BEHRING, Elaine; BOSCHETTI, Ivanete; LIMA, Rita de Lourdes de (ORGs). Marxismo, 
política social e direitos. São Paulo: Ed. Cortez, 2018. pp. 253-272.

HOLLANDA, Sérgio Buarque. Capítulos de História do Império. São Paulo: Companhia das Letras, 2010.

LACOMBE, Américo Jacobina. À sombra de Rui Barbosa. São Paulo: Companhia Editora Nacional; Brasília: INL, 1978.

LAMOUNIER, Bolívar. Rui Barbosa e a construção institucional da democracia brasileira. Rio de Janeiro: Nova Frontiera, 1999.

LORAUX, Nicole. O elogio do anacronismo. In: NOVAES, Adauto. Tempo e História. São Paulo: Companhia das Letras, 1992. pp. 57-71.

LYNCH, Christian. A utopia democrática: Rui Barbosa entre o Império e República. In: SENNA, Marta de. Rui Barbosa em perspectiva: seleção de textos fundamentais. Rio de Janeiro, Fundação Casa de Rui Barbosa, 2007. pp. 37-66. .Ascensão, fastígio e declínio da Revolução Judicialista. Insight Inteligência, n. 79, out./nov./dez. 2017, p. 158-168.

MIGUEL, Luís Felipe. Democracia e representação: territórios em disputa. São Paulo: Ed. Unesp, 2014.

NOBRE, Marco. Imobilismo em desenvolvimento: $\mathrm{Da}$ abertura democrática ao governo Dilma. São Paulo: Ed. Companhia das Letras, 2013.

ORTELLADO, Pablo. Em 20 centavos: a luta contra o aumento. São Paulo: Veneta, 2013.

PINHA, Daniel. Junho de 2013: crítica e abertura da crise da democracia representativa brasileira. Revista Maracanan. N. 8. 2018.

$\mathrm{RE}$, Flavia Maria. Ideias em ação: liberalismo e reforma no pensamento de Rui Barbosa. Tese de Doutorado: USP, 2006.

SANTOS, Wanderley Guilherme dos. A democracia impedida: o Brasil no século XXI. Rio de Janeiro: FGV, 2017.

SECCO, Lincoln. As jornadas de junho. In: MARICATO, Ermínia; VAINER, Carlos; HARVEY, David (ORGs). Cidades Rebeldes: passe livre as manifestações que tomaram as ruas do Brasil. São Paulo: Boitempo; Carta Maior, 2013. pp. 23-37.

SCHERER-WARREN, Ilse. Redes emancipatórias: nas lutas contra a exclusão e por direitos humanos. Curitiba: Editora Appris, 2012.

SINGER, André. Brasil, junho de 2013: classes e ideologias cruzadas. Novos Estudos, n 97, novembro de 2013.

SOUZA, Jessé. A radiografia do golpe. Rio de Janeiro: Leya, 2016. 
O BACHARELISMO INTERVENTOR NO PENSAMENTO POLÍTICO

REVISTA ESTUDOS POLÍTICOS Vol. 10 | N.1 ISSN 2177-2851

BRASILEIRO: UMA ABORDAGEM

COMPARATIVA ENTRE RUI BARBOSA

E RODRIGO JANOT

Rodrigo Perez Oliveira 